Orbis Tertius, vol. XXII, n 25 , e039, junio 2017. ISSN 1851-7811

Universidad Nacional de La Plata

Facultad de Humanidades y Ciencias de la Educación

Centro de Estudios de Teoría y Crítica Literaria

\title{
Ulrico Schmidl, Derrotero y viaje a España y Las Indias.
}

\author{
Introducción, cronología, bibliografía y notas de Loreley El Jaber \\ Paraná, EDUNER, 2016, Colección El País del Sauce, 337 páginas.
}

\section{Juan Ignacio Pisano}

La reedición de un texto colonial desde la industria editorial argentina es, incluso a priori, un hecho a celebrar. Sobre todo si se tiene en cuenta que, para la crónica aquí considerada, se carecía de una edición actualizada, que se llevara a cabo desde una perspectiva crítica más contemporánea y que contemplara nuevos desarrollos de los estudios literarios. Loreley El Jaber, quien es especialista en crónicas del Rio de la Plata, ha tenido a cargo la "Introducción”, la "Cronología”, la "Bibliografía”, "Notas” y la selección de un conjunto importante de imágenes que acompañan al texto de Schmidl. Destaco punto por punto cada uno de los paratextos que completan la edición de esta crónica porque merecen ser mencionados ya que exponen, en su detalle y especificidad, un trabajo inmenso que abre la lectura para un público amplio pero que, también, habilita la labor académica. Se trata de una edición que, sin dudas, será referencia para leer a Schmidl de acá hacia el futuro.

La tapa del libro expone una imagen rectora para la lectura que propone El Jaber en el cuerpo hundido del soldado que allí se representa. Esa imagen es "la del cuerpo viviendo en carne propia los avatares y sufrimientos de un territorio hostil: hambre, guerra, peleas internas, alianzas y enemistades, sed, hidropesía, bichos que muerden y comen la carne, animales monstruosos” (p. XXVI). El Río de la Plata fue un espacio adverso para el europeo, como cuentan los cronistas (además de Schmidl, Álvar Núñez, por caso). No consiguen alimento y, cuando lo hacen, se trata de ingestas escasas. Así lo cuenta Schmidl cuando dice que "Uno no se preocupaba ni por oro ni plata ni por comida ni por otros bienes, sino por el agua” (p. 97); aunque, en otras ocasiones, "todo estaba devastado y deshecho en el camino, que no hallamos nada que comer" (p. 85).Se trata de un "país malsano", como lo llama el soldado alemán que narra esta crónica, y como lo recupera El Jaber en el título del libro que devino de su tesis de doctorado, Un país malsano. La

Cita sugerida: Pisano, J. I. (2017). [Revisión del libro Derrotero y viaje a España y Las Indias por Ulrico Schmidl]. Orbis Tertius, 22(25), e039._https://doi.org/10.24215/18517811e039 
conquista del espacio en las crónicas del Río de la Plata (siglos XVI y VII), publicado en el 2011.

De este modo, el relato que brinda Schmidl cobra un sentido específico, en esta edición, desde el paratexto icónico principal. La imagen, en todo su simbolismo, anticipa un núcleo central productor de significado en el libro. Pero, además, representa una idea que se observa en la edición, ya que se trata de una que coloca en posición destacada a la imagen sobre el Río de la Plata en época de Schmidl, en un cruce donde texto e imagen, crónica y representación pictórica, combinan sus lenguajes para darle al lector un mapa de reconstrucción del contexto en su anclaje espacial mediante la lectura—una reconstrucción posible, claro, nunca definitiva. Como señala El Jaber, en esta discursividad “espacio y sujeto se significan mutuamente”: el espacio otorga sentido al sujeto y el sujeto, con su carga imaginaria y simbólica, dota de significado al espacio al punto de que incluso "pueden devenir materia intercambiable” (p. XXXIV).

La crónica de Schmidl posee un valor particular dado que, como El Jaber sostiene en la "Introducción”, se trata de un escrito que inaugura, sin saberlo ni proponérselo, una tradición que vincula al espacio rioplatense con la literatura. Uno puede pensar, así, no sólo en otros textos coloniales, sino también en dar un salto temporal e intertextual con el siglo XIX. Tómense, por caso, dos textos canónicos para la región: el Facundo de Domingo F. Sarmiento y, antes, La cautiva, de Esteban Echeverría, que hacen del "desierto" el objeto espacial de un deseo de escritura. Qué hace el escritor, se preguntaba el por entonces, sin saberlo ni, tal vez, preverlo, futuro presidente de la Nación, al levantar la vista, dirigirla al desierto “y ver... no ver nada; porque cuanto más hunde los ojos en aquel horizonte incierto, vaporoso, indefinido, más se aleja, más lo fascina, lo confunde y lo sume en la contemplación y la duda” (p. 93). Sarmiento recomendaba fundar allí, en ese paisaje incierto (en su interpretación de ese espacio), bajo una mirada teñida del sublime romántico, la literatura argentina. Teniendo en cuenta esa tradición que luego se instaurará, Schmidl puede considerarse como el “fundador de una espacialidad discursiva que luego será propiamente rioplatense” (p. XXXV).

La de Ulrico Schmidl es la crónica de un soldado, lo cual otorga un locus particular de enunciación a su palaba. Es la voz del común la que emerge en su narración, y es desde esa posición de enunciación que "muestra [...] que en el Río de la Plata la única heroicidad posible es vivir el espacio con toda su hostilidad, sobrevivir a él” (p. XXII). Sobrevivir, podría agregarse, para contarlo.

Ahora: “¿Cómo hacer de esta porción descubierta de América, una porción de tierra deseada?” (p. XV). ¿Cómo lograrlo cuando la muerte y el hambre lo dominan todo, cuando "de los cuatrocientos hombres han muerto en este viaje cincuenta” (p. 22)? El modo que encuentra este alemán para resignificar su viaje de derrota y fracaso se define en el mundo editorial, como sostiene El Jaber en la "Introducción". Porque si la expedición fue un fiasco en términos de conquista material para el imperio, no lo termina siendo como relato y escritura para el propio Schmidl y sus editores. El fracaso del espacio geográfico transmuta en éxito en el espacio del libro. Como señala El Jaber, existía un mercado editorial para este tipo de aventuras a mediados del siglo XVI. Un público ávido por consumir narraciones de viajes insólitos, en espacios desconocidos, de territorios que albergan costumbres y humanos cuyas características resignifican la espacialidad visitada, la vuelven paisaje de un exotismo.

Un rasgo destacable de ese exotismo es el canibalismo, pero no sólo el que realiza el indio, sino también el que lleva a cabo el español. Esa ingesta de carne humana, representada en una imagen de De Bry que se encuentra entre los paratextos seleccionados por El Jaber, ocurre en un momento particular: "Esto ha sucedido en el año 1535 en nuestro día de Corpus Cristi en el susodicho pueblo de Buenos Aires”, dice Schmidl. Paradoja más que simbólica: el día de la celebración religiosa de la Eucaristía, ceremonia donde el cuerpo del salvador ocupa un lugar central, es metaforizado en la salvación de muerte por hambre en la ingesta de carne humana. Nada se multiplica aquí, donde el espacio aún no se encuentra al alcance de la mano del Salvador. Todo, excepto el padecer, se reduce: el cuerpo tajeado, la esperanza de la riqueza, el 
límite ante la otredad; esa otredad que el propio De Bry dibujó-y cuyas representaciones también acompañan esta edición.

Más allá de eso, el repertorio de imágenes seleccionadas por El Jaber se puede dividir en dos grupos: además de las imágenes de humanos, como las mencionadas, los mapas. En ambos casos, el protagonista sigue siendo el espacio. Ya que si bien aquellas que tienen como objetivo representar al Río de la Plata como territorio son los mapas, las imágenes humanas están marcadas por el espacio. Por caso, la ingesta de carne humana es impuesta por las condiciones de esa tierra "malsana".

No se debe dejar de mencionar el monumental trabajo de archivo por parte de El Jaber que guarda esta edición. Esto no sólo brinda al lector todo ese conjunto de imágenes (de las cuales solo se mencionaron algunas, pero habría que hacer notar también litografías de batallas, de poblaciones indias, de naufragios, entre otras), sino que también expone un descomunal apartado de documentos transcriptos y fotografías de los originales de Schmidl que ocupan casi cien páginas. Es decir, que la edición no solo otorga un bagaje del imaginario de la época en imágenes y en la palabra especializada de El Jaber; también brinda la palabra de los contemporáneos a Schmidl y la letra del propio autor.

La primera edición del libro de Schmidl, según informa El Jaber, se produce en 1567 y lleva el siguiente sugestivo título:

Verídicas descripciones de varias navegaciones, como también de muchas partes desconocidas, islas, reinos y ciudades... también de muchos peligros, peleas y escaramuzas entre ellos y los nuestros, tanto por tierra como por mar, ocurridos de una manera extraordinaria, así como de la naturaleza y costumbres horriblemente singulares de los antropófagos, que nunca han sido descriptas en otras historias o crónicas, bien registradas y anotadas para utilidad pública.

A lo largo de los años siguientes, el libro tiene un total de ocho ediciones y un éxito importante. Pero lo destacable de los diversos títulos que el libro adquiere de manos de los sucesivos editores es que en todos los casos se recalca que se trata de un espacio desconocido, despertando el hambre por tomar contacto con esa ausencia de saber, y, al mismo tiempo, en el rasgo de lo extraordinario, reafirmando así una política editorial orientada al éxito, tal como sostiene la hipótesis de El Jaber.

El relato de Schmidl puede ser pensado, indica la especialista a cargo de la edición, a partir de acciones que son prescriptas por el espacio y espacios que son imaginados desde esas mismas acciones y que, en un efecto retroactivo de alimentación topográfica, son demandadas por el espacio. Los mapas, y su inclusión en los apéndices de la edición de EDUNER, permiten ver cómo los mismos reúnen "lugares heterogéneos, unos recibidos de una tradición [que en este caso es la del imaginario del lector europeo sobre América] y otros producidos por una observación [la del propio Schmidl]", si se atiende a la perspectiva que propone Michel De Certeau en el capítulo IX, "Relatos del espacio", de su ensayo. La invención de lo cotidiano I. Artes de hacer. Esa dialéctica donde "una tradición” se conjuga con una lectura demandada por el público contemporáneo a Schmidl, sumada a aquel juego irrenunciable donde lo imaginario, lo simbólico y lo real (el espacio hostil)actúan sobre la letra escrita, emergen, como un horizonte potencial, en esta esmerada edición ante la mirada del lector actual. Un acercamiento que cala profundo en la búsqueda de una reconstrucción imposible en su plenitud, pero visible en el trabajo de un proyecto editorial y palpable en la materialidad del libro: la reconstrucción de un pasado desde la lectura en presente, desde lo más actual de la crítica literaria. Puede leerse, así, en espejo la actividad de la compiladora con el recorrido del soldado. Esta edición se pone en juego entre el derrotero espacial de Schmidl y la entrega a un archivo por parte de la investigadora. 
El cuerpo sumergido en el agua que la tapa del libro muestra es, entonces, como el cuerpo dela archivista entre sus papeles. Una voluntad férrea los aúna, aunque sus imaginarios los separen indefectiblemente. Entre ese contacto y esa separación, allí es donde se ubica este libro tan bienvenido. 